\title{
Twenty-first century healthcare: delivering the promise against the reality
}

Welcome to the December issue of Clinical Medicine. I hope you will all have some downtime with family and friends over the holiday period and maybe even find time to enjoy this offering, maybe while relaxing with some festive fare. This edition contains the usual breadth of high quality manuscripts that provide the jobbing physician practical updates and thoughtprovoking research.

To me several themes came to the fore in this issue. First, it brings home the advances we continue to witness and embrace in medicine, whether in pharmacotherapy, diagnostics or genetics. Additionally, the issue highlights the trade-off between these (often initially costly) advances and the provision of equitable healthcare for all; the increasing need for simply understood algorithms to identify patients who require further care; and how we maintain the fundamental tenets of clinical medicine in this technologically driven era.

At the global level, Chris Whitty's wide ranging Harveian oration $^{1}$ encapsulates much of this, highlighting the improving global trends in public health across all ages, secondary to advances in healthcare capability, but also raising the issues of behavioural and economic reality that are often overlooked.

These latter points are critical, as while we should rightly celebrate the significant health gains globally and the contribution of UK healthcare, we must also acknowledge the reality of a NHS in turmoil and the limitations we currently face and must overcome if we are to optimise and maintain this success.

In the UK, the combined constraints of funding, staffing and training challenges must be continually acknowledged and challenged. In a nutshell we have, in my opinion, reached the point where we need a far more open and public debate on what we, as a society, are willing to pay for and staff against; we need to leverage the best available resources, agree the number of staff we can meaningfully sustain over their careers, and debate how much time we are willing to fund in order to ensure we have the time and energy to train future generations, reflect on our practice, and ensure we do not lose our compassion through burnout and cynicism.

Ultimately, we must remember that medicine is above all a human endeavour, with dedicated staff caring for others in their hour of need. To sustain our compassionate profession, both in the UK and globally, we need to maintain the care to the carers. In this edition we are presented with balanced evidence and debate as to the protection influenza vaccination gives to staff, as well as patients, ${ }^{2}$ and reflect on dwindling time for training and mentorship, specifically in the fundamentals of medicine (ie history taking and - as covered in this edition physical examination ${ }^{3}$ ). We must not accept the risk of failing to teach the art of medicine in the era of technology, because to do so would start to unpick the golden thread of human compassion towards those for whom we care; a thread that has been built on 500 years of endeavour.

This may be a salient point to end on at this time of year; goodwill to all men (and women) and all that. May I wish you all a happy Christmas (whether you celebrate it or not) and hope that 2018 and our 500th year brings you all you desire.

\section{References}

1 Whitty CJM. Triumphs and challenges in a world shaped by medicine. Clin Med 2017;17:537-44.

2 Pereira M, Williams S, Restrick L et al. Healthcare worker influenza vaccination and sickness absence - an ecological study. Clin Med 2017;17:484-89.

3 Elder AT, I Chris McManus IC, Alan Patrick A et al. The value of the physical examination in clinical practice: an international survey. Clin Med 2017;17:490-8.

Wing Commander Ed Nicol Editor-in-chief

\begin{tabular}{|c|c|c|c|}
\hline \multicolumn{4}{|c|}{ Members of the editorial board } \\
\hline $\begin{array}{l}\text { Wing Commander Edward Nicol } \\
\text { Editor-in-chief } \\
\text { Cono Ariti } \\
\text { Statistical editor } \\
\text { Dr Michael Almond } \\
\text { Mr Paul Belcher } \\
\text { Prof Rodger Charlton } \\
\text { Dr Tim Chevassut }\end{array}$ & $\begin{array}{l}\text { Prof Tahseen Chowdhury } \\
\text { Dr Nick Cork } \\
\text { Dr Albert Edwards } \\
\text { Dr Kate Evans } \\
\text { Dr Johanna Feary } \\
\text { Dr Maggie Hammersley } \\
\text { Dr Dylan Harris } \\
\text { Prof Brian Hurwitz } \\
\text { Dr Nicola Jones } \\
\text { Dr Vikas Kapil }\end{array}$ & $\begin{array}{l}\text { Dr Alexandra Lake } \\
\text { Dr Tom Levett } \\
\text { Dr Nicola Lomax } \\
\text { Prof Philip MacCarthy } \\
\text { Prof Yash Mahida } \\
\text { Dr Chris Marguerie } \\
\text { Dr Ravik Mascarenhas } \\
\text { Prof Martin McKee } \\
\text { Dr Andrew Medford } \\
\text { Dr Rahul Mukherjee }\end{array}$ & $\begin{array}{l}\text { Dr Mehool Patel } \\
\text { Dr Gerrard Phillips } \\
\text { Dr Roby Rakhit } \\
\text { Dr Jo Rimmer } \\
\text { Prof Phil Smith } \\
\text { Dr Angela Star } \\
\text { Prof Cameron Swift } \\
\text { Dr Rhys Thomas } \\
\text { Dr Duncan Wilson } \\
\text { Dr Juliet Wright }\end{array}$ \\
\hline
\end{tabular}

